\title{
Les Noirs dans le Monde
}

A SPECIAL number of Echanges ${ }^{1}$ (published in Paris by the Auxiliatrices du Purgatoire) is devoted to studies of Africans, more particularly in their contacts with other civilizations. As well as articles on such topics as ' $L$ 'Afrique noire en quête d'une équilibre', 'Proverbes dahoméens ', ' $\mathrm{La}$ Culture orale ', 'L'Univers religieux négro-africain ', there are papers on racial and colour questions. Several of the authors are well-known contributors to Présence Africaine, the most recent number of which deals with some of the same topics.

\section{United Nations Trusteeship Council}

THE Committee on Rural Economic Development in the Trust Territories was established by the Trusteeship Council at its eighth session (3 18 th meeting), to:

' study the prevailing policies, laws and practices which in the Trust Territories relate to land, land utilization and the alienation of land, taking into account the present and future needs of the indigenous inhabitants, and the future economic requirements of the said Territories, as well as the social and economic consequences of the transfer of land to non-indigenous inhabitants. (Trusteeship Council resolution 305 (VIII).)

The Committee commenced its wotk in March I9S I and has submitted five progress reports to the Council. The Committee has now accumulated a very considerable volume of documentation and has secured information from the Administering Authorities on various aspects of land tenure, land utilization, \&c. The information so obtained has been assembled by the Secretariat in the form of comparable working papers for each Trust Territory on (a) land legislation and $(b)$ the distribution of population and categories of land, the amount of land in each category held by indigenous and non-indigenous inhabitants, and the form of tenure under which such land is held. The memoranda submitted by the Administering Authorities and the working papers prepared by the Secretariat constitute the T/AC.36/L ... series, which now number fifty-nine. In addition, FAO and WHO have submitted papers dealing respectively with land utilization and health in the Trust Territories and the Secretariat is in the process of preparing a study on land tenure and land utilization.

The Committee now feels, therefore, that sufficient basic data have been collected to enable it to commence the second phase of its work, i.e. to initiate the actual studies entrusted to it by the Council. For this purpose the Committee has tentatively approved an outline for its report (T/AC.36/L. 46 and Corr. I). According to this outline, the report is to be divided into three parts: part $\mathrm{I}$, on rural economic development in Trust Territories-a general synoptic survey covering land tenure and land utilization in the Trust Territories; part II, on land, land utilization, and the alienation of land in individual Trust Territoriesa factual survey of existing conditions in the Territories; and part III, containing conclusions and recommendations.

\section{Cercle Soudanais d'Études traditionnelles}

IL est créé, à Bamako, Soudan français, une association dont le but est de recueillir les monuments de la tradition soudanaise, sous quelque forme qu'ils se présentent, et de faire connaître par les moyens de diffusion habituels cette tradition. Les travaux que les membres actifs doivent fournir constitueront l'élément principal des archives. Les méthodes de diffusion seront des conférences, des sections établies dans les centres de province, des articles donnés à des périodiques apolitiques. Est membre actif toute personne qui a fourni un travail retenu par le Comité de lecture, et qui verse une cotisation annuelle; toute personne

I No. 3I, Pentecôte 1957. 
qui, ayant publié un ouvrage d'ordre scientifique sur l'Afrique, postule et verse sa cotisation. L'Assemblée générale des membres du Cercle se réunira au moins une fois par an.

\section{African Study Centre in the Netherlands}

THE African Study Centre at the University of Leyden was originally a branch of the Afrika Instituut in Rotterdam, which was mainly concerned with economic and commercial questions. The centre at Leyden has now developed into a centre for linguistic and sociological studies, available to students of the University. Lecturerships in African Linguistics, Ethnology, and Sociology have been founded.

\section{Field Research in Liberia}

Mr. James L. Grbbs, Jr., is undertaking a field study of the customary law of the Kpelle tribe of Gbarnga District, Central Province, north of Monrovia. His research, which is sponsored by the Ford Foundation, New York, will be devoted particularly to a study of judicial procedure and the function of law as an instrument of social control.

\section{Catalogue of Publications in the Bantu Languages of Southern Africa}

The Conference on Christian Literature for the Bantu of Southern Africa, held in Johannesburg in August 1956, stressed the necessity of publishing a catalogue of all Christian publications available in the Bantu languages of Southern Africa. 'Informo' (Christian Literature Service, Secretary J. Semmelink) has undertaken to prepare such a catalogue, and a preliminary list based on information supplied by publishers, has been duplicated and circulated. It includes titles in Pedi, Sotho, Xhosa, Zulu, Tswana. When more or less complete lists for any one language have been compiled, periodic supplements will be issued, as well as separate lists of, for example, periodicals, linguistic publications, school-books, \&c.

\section{Light on Nigeria's History}

A reasonably certain date has now been arrived at for the Nok sculptures, ${ }^{\mathrm{I}}$ whose discovery in 'Middle Belt' areas of Northern Nigeria in recent yeats radically alters all conceptions of Nigerian history. It was always clear that the existence of such sophisticated work, probably at least 1,000 years old, in areas of Nigeria now considered 'backward', made nonsense of common notions of African history. But there has been some doubt about their date, and Mr. Bernard Fagg, who is chiefly responsible for their discovery, would never commit himself on it.

Now news has been received that the latest samples of semi-carbonized wood, found embedded in the middle of the main bed of grey-black clay, which marks the final phase of the Nok Figurine Culture, have been analysed for their radiocarbon content at Yale University and have proved to be 1,750 years old (with a probable margin of error of only so years each way), which makes the very end of the Nok Culture date from about A.D. 200.

Some semi-carbonized wood samples from the gravels below the clay where most of the figurines have been found, which were collected in I950 and finally analysed in December 1956, suggest that the Nok figurines probably date back at least to about 900 B.C. Such a date dispels the scepticism with which the tentative date for this sophisticated art of the Nok people, and for the introduction of metal-working, was previously received. It gives, too, the first relatively firm date for the prehistoric cultures of West Africa, from which studies can develop both forwards and backwards in time.

\footnotetext{
I See Africa, xv, 1945, pp. 21, 22.
} 